\title{
An application of the plant functional group concept to restoration practice on coal mine spoil heaps
}

Received: 26 September 2013/ Accepted: 15 June 2014 / Published online: 2 July 2014 (C) The Author(s) 2014. This article is published with open access at Springerlink.com

\begin{abstract}
The history of coal mining in South Poland has left a legacy of many spoil heaps across the landscape. These have presented the opportunity to study their colonisation and spontaneous successional sequences over a long time period. We use the plant functional group (PFG) approach to characterize and compare species diversity on spoil heaps of different ages by utilising the ecological characteristics (PFG categories) of the species recorded during the course of spontaneous vegetation development. By changing species frequency into functional group frequency it was possible to find the significant differences in the functional composition of the studied vegetation and to analyze the dataset using non-parametric statistics. There was a small increase in the number of species over time, while the frequency of geophytes, nanophanerophytes and megaphanerophytes increased significantly. A significant increase was also recorded for the frequency of competitors, stress-tolerators and stress-tolerant competitors and for native species. We found that the significant differences in species composition measured as PFG diversity occurred between the youngest and the oldest age classes. The PFG approach provided valuable insights into the nature of the species composition of the developing vegetation on hard-coal mine spoil heaps. We suggest that it could be usefully applied in restoration practice in the future by facilitating the natural colonization of native species adapted to local conditions and thus retaining the local gene pool in these areas.
\end{abstract}

\footnotetext{
A. Piekarska-Stachowiak

Department of Biophysics and Morphogenesis of Plants,

University of Silesia, Jagiellońska 28, 40-032 Katowice, Poland

E-mail: anna.piekarska@us.edu.pl

M. Szary $\cdot$ B. Ziemer · G. Woźniak $(\bowtie)$

Department of Geobotany and Nature Protection, University

of Silesia, Jagiellońska 28, 40-032 Katowice, Poland

E-mail: gabriela.wozniak@us.edu.pl

L. Besenyei

Faculty of Science and Technology, University of Wolverhampton, Wulfruna St., Wolverhampton, UK
}

Keywords Man-made habitat - Dominant species group - Ecological process - Spontaneous succession . Life strategies · Life-form · Plant functional groups

\section{Introduction}

The scale of human activities on the earth has resulted in most ecosystems being disturbed in some way (Ehrlich 1993). One of the main human activities which has directly altered land cover across Europe is the mining industry (Bradshaw 1992). The main impact of this activity is the inevitable creation of post-industrial waste sites such as spoil heaps associated with hard coal mining.

These coal mine spoil heaps are places where the stone material, extracted together with the coal, has been stored after extraction. These sites are often subject to extreme abiotic conditions (e.g., lack of water, low nutrient availability, high temperature, high salinity) (Bradshaw 1993). The material heaped in spoil does not contain organic carbon derived from recent plant material; similarly, the amounts of nitrogen and phosphorus are also low. Each of these limits biological activity (Šnajdr et al. 2013) and thus the biological development of this environment is very slow (Urbanová et al. 2011).

However, over time hard coal mine spoil sites, despite their adverse conditions, are effectively colonized by plants and animals, which promote the development of vegetation. There are many studies on spontaneous succession on post-industrial sites from Central Europe (Cohn et al. 2001; Prach 2003; Woźniak et al. 2003; Rostański and Woźniak 2007; Frouz et al. 2008; Rahmonov 2009; Chmura et al. 2011; Rahmonov et al. 2011; Kompała-Baba and Bạba 2013; Chmura et al. 2013), but still some of the processes occurring in these man-made environments are poorly understood especially in terms of their functional diversity (Prach et al. 1997; Cabała et al. 2004; Latzel et al. 2011; Woźniak et al. 2011) and the ecosystem services they provide. 
There are many studies showing the intensity and diversity of species and vegetation patches recorded during the development of spontaneous processes on some of these post-industrial sites (Kompała et al. 2004; Rostański 2005; Woźniak 2006). There is an increasing understanding that biodiversity is relevant to ecosystem properties. The relation is manifested in the best way through plant functional diversity (Díaz et al. 2007). This trait-based view of community diversity may be more meaningful than species richness or the species composition of the diversity (Cadotte et al. 2011). However, the precise relationship between species richness and functional richness is unresolved for most natural systems (Naeem 2002). Wang and Chen (2013) underlined that the type of traits which may occur and how these may vary with plant succession is far from being fully understood. The spontaneous development of the vegetation on post-industrial sites represents a model situation of de novo ecosystem development. On such sites we can learn about the changes and differences in functional structure by analyzing vegetation records obtained from chronosequence studies like those presented here.

In this study the changes in plant functional group (PFG) composition of species over time were studied in order to understand how the spontaneous vegetation development progresses. By utilising the PFG concept and converting each species frequency into its component functional group types it is possible to analyse the dataset using non-parametric statistical tests. This functional approach arises because it has been stated that different groups of organisms show redundancy, which means that any loss of taxonomic diversity does not necessarily have to result in a loss of function of the whole system (Rosenfeld 2002).

The aim of this study was to convert the recorded diversity of vegetation species composition of coal mine spoil heaps into its component PFG types and to test whether the composition of the PFG types differs be- tween the studied age classes. We expect that the number of PFG types will increase with time.

\section{Methods}

Study site

The study was carried out on coal mine spoil heaps located in the Silesian Upland of southern Poland. The climate of the area is temperate with a mean annual precipitation of ca. $580 \mathrm{~mm}$ and a mean annual temperature of $7.6^{\circ} \mathrm{C}$. Coal mine spoil heaps provide habitats which consist of a pure mineral substrate and can temporarily be extremely warm $\left(50{ }^{\circ} \mathrm{C}\right.$ at about noon in summer) compared with their surroundings, but with no differences in precipitation (Woźniak 2010). The vegetation samples (Table 1) were taken from 28 coal mine spoil heaps at 18 different coal mines within the region. The coal mine spoil heaps are usually built of carboniferous gangue with unfavorable soil texture (mainly clay stone and siltstone, also sandstone, conglomerate, coal shale) with small admixtures of coal. The chemical characteristics of the soil are presented in Table 2. The characteristics of the soil substrate of the study plots were determined using standard methods in the Soil Analysis Laboratory of the Faculty of Biology and Environmental Protection, University of Silesia: $\mathrm{pH}, \%$ of moisture, available $\mathrm{P}, \mathrm{K}$ and $\mathrm{Mg}$, organic carbon, content of $\mathrm{NH}_{4}$ and conductivity (data from Woźniak 2010; Woźniak et al. in press).

Such sites are often subject to extreme abiotic conditions, e.g., poor water retention, lack of water, fast drying of the surface layer, low nutrient availability, low levels of organic matter, high temperature (reaching $50{ }^{\circ} \mathrm{C}$ and endogenous thermal activity), differing salinity levels-crystallized salt can sometimes be observed (Woźniak 2010).

Table 1 The scheme of permanent plots with the most frequent dominant species groups present in the vegetation established on coal mine spoil heaps of increasing age

\begin{tabular}{|c|c|c|c|c|}
\hline \multirow[t]{2}{*}{ Dominant species present in the permanent plots } & \multicolumn{4}{|c|}{ Heaps of different ages } \\
\hline & Class I & Class II & Class III & Class IV \\
\hline $\begin{array}{l}\text { Tussilago farfara } \\
\text { Poa compressa } \\
\text { Chamaenerion palustre } \\
\text { Calamagrostis epigejos } \\
\text { Daucus carota } \\
\text { Melilotus alba } \\
\text { Populus tremula } \mathrm{b} \\
\text { Pinus sylvestris } \mathrm{b} \\
\text { Betula pendula } \mathrm{b} \\
\text { Betula pendula } \mathrm{a} \\
\text { Quercus robur a } \\
\text { Pinus sylvestris } \mathrm{a}\end{array}$ & $\begin{array}{l}++++ \\
++++ \\
++++\end{array}$ & $\begin{array}{l}++++ \\
++++ \\
++++\end{array}$ & $\begin{array}{l}++++ \\
++++ \\
++++\end{array}$ & $\begin{array}{l}++++ \\
++++ \\
++++\end{array}$ \\
\hline
\end{tabular}

++++ denotes the dominant species was present in plots at all sites in each of the age classes; letter "a" after the species name indicates the tree form, letter " $b$ " after species name indicates the shrub form, species name without letter indicates the herb layer 


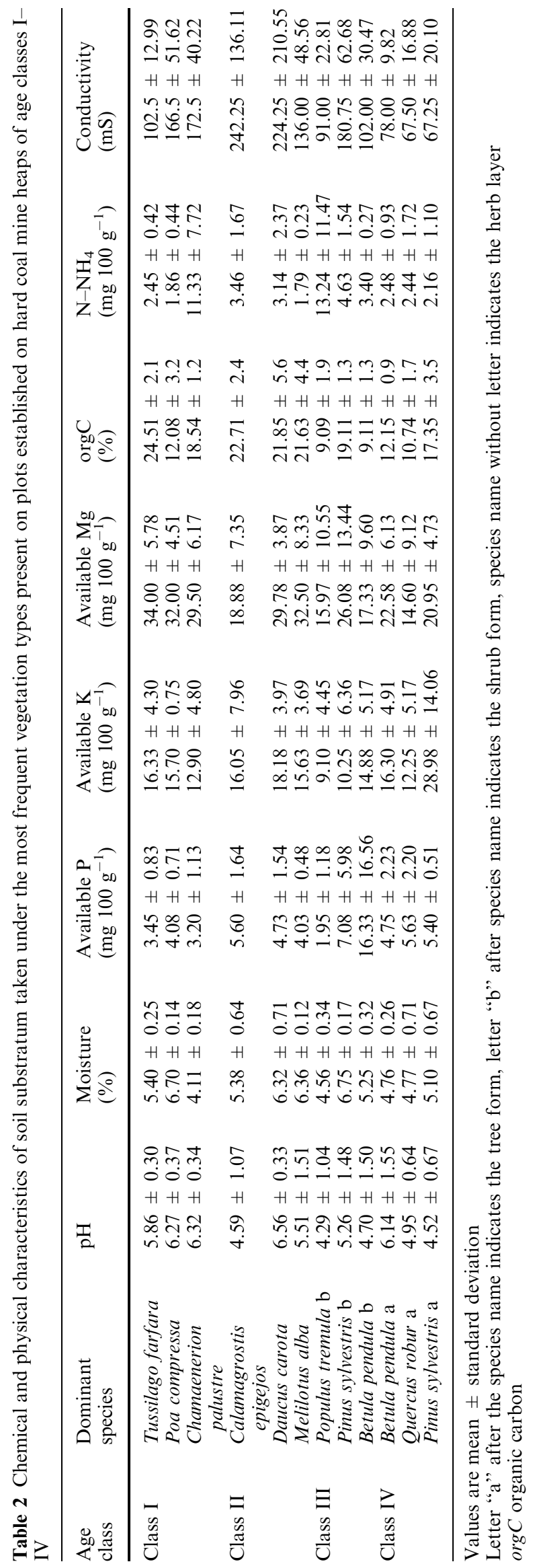




\section{Vegetation sampling}

All of the heaps were divided into four age classes (class I - up to 10 years old; II 10-30 years old; III-30-60 years old; IV - over 60 years old) based on the recorded date for the end of deposition of the heaps. This information was obtained from the administrative office of each of the coal mines studied and from published information (Woźniak 2010). The distribution of the spoil heaps that were studied are shown in the map in Fig. 1.

A preliminary study of the spoil heaps enabled the preparation of a list of the most frequent vegetation types found within each age class. This list provided the basis for choosing the patches for establishing the permanent plots of $2 \times 2 \mathrm{~m}$. These were chosen by the stratified sampling of the heaps for their vegetation types on heaps of differing ages. In this way we avoided studying randomly sampled vegetation patches which could have happened by using a totally random, or systematic, sampling design. The samples of the same vegetation types were taken from separate heaps of the same age within similar geographical locations, so as not to change the abiotic characteristics (Fig. 1). Table 1 shows the list of vegetation types (as defined by their dominant species) within each age class. The species composition was recorded within 48 plots (of 12 vegetation types) in four replicates of each heap age class over 10 years. The distribution of the spoil heaps in each age class is shown on the map in Fig. 1.

\section{Analytical methods}

Each species recorded was characterised into its different PFG traits in terms of its life-form, life strategy and its geographical-historical group (Table 3). The life-form scheme characterizes plants in terms of their strategy to survive in unfavorable seasons (Raunkiaer 1934), which is particularly important in the severe conditions of postindustrial waste sites. Grime's life strategy classification describes the trade-off that organisms face when the resources they gain from the environment are allocated between growth, maintenance or regeneration - known as the universal three-way trade-off (Grime 1977). Plants utilizing the Competitor strategy facilitate their survival by using methods that maximize resource acquisition and resource control in consistently productive niches.



Fig. 1 Location of heaps in the area of the Silesian Upland, South Poland. 1 geographical region, 2 towns and cities, 3 state border, 4 border of Silesian Upland, 5 minor geographical borders, 6 rivers and lakes, 7 heaps in age class I; 8 in age class II, 9 in class III, 10 in class IV 
Those plants using a stress-tolerant strategy maintain metabolic performance in variable and unproductive niches. Species with a Ruderal strategy accomplish rapid completion of their lifecycle and regenerate in niches where events are frequently lethal to the intermediate strategies. The use of geographical-historical groups (Krawiecowa and Rostański 1972) characterizes the analyzed species in terms of their origin, and thus determines the native and alien plant species and, therefore, defines at which developmental stage the participation of alien species is the highest within the vegetation.

Thus the recorded species composition was transformed into PFG composition. The list of species recorded in each plot was replaced by a list of PFG categories the species were represented by. The frequency of species representing the same PFG category in each plot from the same heap age class was summarized. In this way the proportion of species representing each of the analyzed PFG categories (ecological features) on plots from one age class could be analyzed. For all plots within each age class the following calculations were performed: number of species (total number of species recorded on all permanent plots on heaps of a particular age class during 10 years of observations); sum of species presence (sum of the presence of all species recorded on all permanent plots of heaps of a particular age class during 10 years of observation). After these calculations it was possible to obtain PFG category frequency. This was then analysed separately for each PFG category for each heap age class.

To test if there were any differences in the participation of species represented by the studied PFG categories the non-parametric Kruskal-Wallis $H$ tests (Zar 1999) was applied to compare the PFG composition of vegetation patches of four heap age classes from the point of view of all of the PFG categories (ecological features separately). Where the test results were significant a multiple comparison of mean ranks for all groups (post hoc test, see Siegel and Castellan 1988) was used to discover which pairs of age classes differed from each other. All statistical analyses were conducted using STATISTICA version 10.0 (StatSoft. Inc. 2011), at the 0.05 significance level.

\section{Results}

A total of 98 vascular plant species were recorded throughout this study in the vegetation patches of coal mine spoil heaps. The number of species and species frequency was found to increase with time (Table 4).

Most of the PFGs were present in the analyzed vegetation patches (Table 5). There are some exceptions,
Table 3 List of ecological features used for characterising the co-occurring species composition

\begin{tabular}{ll}
\hline Source of the species ecological characteristics & Full name \\
\hline Raunkiaer's life-forms (Raunkiaer 1934; Zarzycki et al. 2002) & Therophyte \\
& Geophyte \\
& Hemicryptophyte \\
& Chamaephyte \\
& Nanophanerophyte \\
Grime's life strategies (Grime 1977; Frank and & Megaphanerophyte \\
Klotz 1990; Klotz et al. 2002) & Competitor \\
& Stress-tolerator \\
& Ruderal \\
& Competitive-ruderal \\
& Stress-tolerant ruderal \\
& C-S-R strategist \\
Geographical-historical groups (Krawiecowa and & Stress-tolerant competitor \\
Rostański 1972; Mirek et al. 2002) & Apophyte \\
& Archaeophyte \\
& Neophyte
\end{tabular}

${ }^{a}$ Native species which established on man-made habitats

${ }^{\mathrm{b}}$ Non-native species which established in the country before XVth century

${ }^{\mathrm{c}}$ Non-native species which established in the country after XVth century

Table 4 Number of different species and their recorded sum of frequency in vegetation patches on heaps of different age classes

\begin{tabular}{|c|c|c|c|c|}
\hline & \multicolumn{4}{|c|}{ Heaps of different ages } \\
\hline & $\mathrm{I}$ & II & III & IV \\
\hline Number of species & 42 & 44 & 47 & 47 \\
\hline Sum of frequencies & 385 & 729 & 1016 & 1602 \\
\hline
\end{tabular}


Table 5 Comparison of frequency of the analysed functional groups in vegetation patches on heaps of different age classes

\begin{tabular}{|c|c|c|c|c|c|}
\hline & I & II & III & IV & $\mathrm{H}$ \\
\hline \multicolumn{6}{|l|}{ Life-forms } \\
\hline Therophyte & 61 & 21 & 182 & 5 & $38.31 *$ \\
\hline Geophyte & 86 & 161 & 11 & 291 & $182.96^{*}$ \\
\hline Hemicryptophyte & 169 & 504 & 517 & 492 & $141.36^{*}$ \\
\hline Chamaephyte & 42 & 0 & 0 & 7 & $344.38 *$ \\
\hline Nanophanerophyte & 0 & 0 & 17 & 93 & $189.86^{*}$ \\
\hline Megaphanerophyte & 27 & 43 & 289 & 714 & $385.06^{*}$ \\
\hline \multicolumn{6}{|l|}{ Life strategies } \\
\hline Competitor & 97 & 263 & 612 & 1094 & $344.67 *$ \\
\hline Stress-tolerator & 0 & 0 & 0 & 150 & $372.73 *$ \\
\hline Ruderal & 22 & 1 & 0 & 0 & $51.39 *$ \\
\hline Competitive-ruderal & 71 & 193 & 86 & 0 & $187.67 *$ \\
\hline Stress tolerant ruderal & 40 & 3 & 16 & 75 & $122.67 *$ \\
\hline C-S-R strategist & 138 & 261 & 229 & 163 & $61.80 *$ \\
\hline Stress-tolerant competitor & 17 & 8 & 73 & 120 & $202.63 *$ \\
\hline \multicolumn{6}{|c|}{ Geographical-historical groups } \\
\hline Apophyte & 344 & 706 & 984 & 1586 & $303.75^{*}$ \\
\hline Archaeophyte & 31 & 5 & 19 & 0 & $44.62 *$ \\
\hline Neophyte & 10 & 18 & 13 & 16 & 2.09 \\
\hline
\end{tabular}

Notation: H-the Kruskal-Wallis test of the comparison of plant functional groups

* The results statistically significant chamaephyte representatives occur only in classes I and IV and nanophanerophytes were recorded exclusively in plots on heaps of age classes III and IV. Among the life strategies the stress tolerant species are present only on the oldest heaps. The early introduced species (archeophytes) were not recorded on the oldest heaps. Therophytes occurred most frequently in vegetation patches on heaps of age class III, while geophytes were most frequent on heaps of age class IV. The frequency of hemicryptophytes generally increases with the age of the heaps, however, the hemicryptophytes were the most frequent on heaps of age class III. Megaphanerophytes were most frequent on the oldest heaps as would be expected.

Among the different life strategies the competitors, stress-tolerators and stress-tolerant competitors were most frequent on the oldest heaps. On the youngest heaps species with the ruderal strategy were the most frequent, while on age class II the competitive-ruderals and $\mathrm{C}-\mathrm{S}-\mathrm{R}$ strategists were the most frequent.

The native species were present at the highest frequency on the oldest heaps, while the early introduced species were most frequent on the youngest heaps. The neophytes were not frequent but the highest numbers of them were recorded in vegetation patches of age class II.

A comparison of the participation of plant species from different PFG categories in the vegetation patches of the different age classes showed statistically significant differences for all the variables with the exception of neophytes (Table 5).

The post hoc analyses (Table 6) indicated that the biggest disparity in frequency of the ecological features analyzed was between age classes I and IV. These analyses showed a disparity between all of the life-forms analyzed, the highest similarities were among age classes I and II and II and III. The species representative of the geophyte and hemicryptophyte life-forms were respon- sible for the majority of the differences. The species which represent therophytes differed only between age classes I and IV.

The participation of species represented by the different life strategies in the composition of the studied vegetation also revealed differences. The Kruskal-Wallis tests (Table 5) indicated that the participation of species representing each of the categories among the lifestrategy PFGs differ significantly in the four age classes of vegetation patches analysed. The post hoc test (Table 6) showed that all the analysed variables differentiated the pairs of classes I and II, I and III, I and IV and II and IV. All age classes differed in terms of the participation of species which are competitors and ruderals.

The participation of species representing the geographical-historical groups in the vegetation patches recorded on the studied heaps revealed that only the participation of apophytes (native species which established on man-made habitats) and archaeophytes (nonnative species which established in the country before the XVth century) differed. No significant differences were found for the participation of neophytes (non-native species which established in the country after the XVth century, see Table 5). The multiple comparisons test (Table 6) indicated that the differences in frequency of native species are different in all of the age classes and there were significant differences in the participation of archaeophytes between classes I and II and between classes I and IV.

\section{Discussion}

\section{Diversity changes in time}

In our long-term study we observed a slight increase in species number between all of the four heap age classes. 
Table 6 Multiple comparisons after Kruskal-Wallis test of functional groups recorded in vegetation patches on heaps of different age classes

\begin{tabular}{|c|c|c|c|c|c|c|}
\hline & I vs II & I vs III & I vs IV & II vs III & II vs IV & III vs IV \\
\hline \multicolumn{7}{|l|}{ Life-forms } \\
\hline Therophyte & 0.10 & 0.13 & $0.00 *$ & 1.00 & 0.48 & 0.38 \\
\hline Geophyte & $0.00 *$ & $0.00 *$ & $0.00^{*}$ & 0.10 & $0.00 *$ & $0.00 *$ \\
\hline Hemicryptophyte & $0.00 *$ & $0.00 *$ & $0.00 *$ & $0.02 *$ & 1.00 & $0.00 *$ \\
\hline Chamaephyte & $0.00 *$ & $0.00 *$ & $0.00 *$ & 0.06 & $0.00 *$ & $0.00 *$ \\
\hline Nanophanerophyte & 1.00 & 0.38 & $0.00 *$ & 0.38 & $0.00 *$ & $0.00 *$ \\
\hline Megaphanerophyte & 1.00 & $0.00 *$ & $0.00 *$ & $0.00 *$ & $0.00 *$ & $0.00 *$ \\
\hline \multicolumn{7}{|l|}{ Life strategies } \\
\hline Competitor & $0.00 *$ & $0.00 *$ & $0.00 *$ & $0.00 *$ & $0.00 *$ & $0.00 *$ \\
\hline Stress-tolerator & 1.00 & 1.00 & $0.00 *$ & 1.00 & $0.00 *$ & $0.00 *$ \\
\hline Ruderal & $0.03 *$ & $0.02 *$ & $0.02 *$ & $0.00 *$ & $0.00 *$ & $0.00 *$ \\
\hline Competitive-ruderal & $0.00 *$ & 0.12 & $0.00 *$ & $0.00^{*}$ & $0.00 *$ & $0.00 *$ \\
\hline Stress-tolerator ruderal & $0.00 *$ & 0.06 & $0.00^{*}$ & 0.98 & $0.00 *$ & $0.00^{*}$ \\
\hline $\mathrm{C}-\mathrm{S}-\mathrm{R}$ strategist & $0.00 *$ & $0.00 *$ & $0.00 *$ & 1.00 & $0.00 *$ & 0.11 \\
\hline Stress-tolerant competitor & 1.00 & $0.00 *$ & $0.00 *$ & $0.00^{*}$ & $0.00^{*}$ & $0.00^{*}$ \\
\hline \multicolumn{7}{|l|}{ Geographical-historical groups } \\
\hline Apophyte & $0.00 *$ & $0.00 *$ & $0.00 *$ & $0.00 *$ & $0.00^{*}$ & $0.00 *$ \\
\hline Archaeophyte & $0.04 *$ & 1.00 & $0.01 *$ & 0.72 & 1.00 & 0.21 \\
\hline Neophyte & 1.00 & 1.00 & 1.00 & 1.00 & 1.00 & 1.00 \\
\hline
\end{tabular}

Within a functional group, a significant difference between a pair of age-classes is indicated by * $(p$ value smallest from 0.05$)$

In a theoretical consideration of the changes in species richness that proceed over time Horn (1974) concluded that the richest species assemblages should be those observed in the intermediate age stages of succession. Species may still be present from the earlier stages and those species from the later stage can also start to appear. In our study the vegetation patches recorded on spoil heaps of age classes II and III represented the intermediate stages of vegetation development but the highest species richness was recorded in the last stage - on heaps of age class IV. In this study the use of sum of species presence better reflects the rate of development of the vegetation. The sum species presence was the highest in vegetation patches of the oldest heaps. The increase in frequency was almost $100 \%$ from class I to II and the lowest increase was recorded from class II to III.

There are different opinions as to how diversity changes with time and these are not consistent. Some studies have demonstrated that the diversity of pioneering communities decreases with time (Margalef 1968), while other studies indicated that the species richness increases during the development of the vegetation (Auclair and Goff 1971; Pineda et al. 1981).

Díaz and Cabido (2001) claim that diversity should not be viewed only as species diversity but the composition of genotypes, species, functional groups and that the surrounding landscape is equally or even more important (Chapin et al. 2000; Smith and Knapp 2003) when considering the functional features of the vegetation. Though considerable research has gone into teasing out the linkages between biodiversity, functioning and ecosystem services (Naeem and Wright 2003), the metaanalysis performed by Balvanera et al. (2006) revealed that there are no simple generalizations among species traits, biodiversity and ecosystem properties. Prach (2003) explained how species diversity change and con- sidered the underlying importance of the length of time it takes for the change of dominant species to take place and that the number of species was positively correlated with $\mathrm{pH}$ and mean annual temperatures and negatively with annual precipitation and altitude in the first 10 years of succession.

Cadotte et al. (2011) suggested that it would be useful to evaluate the validity of species richness as a proxy for functional diversity. Nevertheless, the precise relationship between species richness and functional richness remains unresolved for most natural systems (Naeem 2002). By analyzing how the number of PFG categories changed over time it has been shown that the results are variable between the studied PFGs. The number of lifeform categories were the highest in the oldest heap class and lowest in the second age class. For the life strategy categories the results were different with the highest number being recorded in age classes I and II and the lowest in age classes III and IV. The categories of geographical historical groups were the lowest in vegetation patches recorded on the oldest heaps.

Diversity measured by number of species, categories of PFG or other ways of measurements always leads us to miss a very important point - the presence of both rare and endangered species. There are many records showing that particular seral stages often provide refugia for wildlife and the resultant vegetation usually exhibits a higher diversity and natural value than that on technically restored sites (Woźniak and Kompała 2001; Hodačová and Prach 2003; Prach 2003).

\section{Life-form participation}

The analysis of the different life-form categories suggested that the number of species with different life- 
forms increases during the process of succession on coal mine spoil heaps. In the first age class the most frequent life-forms were hemicryptophtes. The second most frequent life-forms were the geophytes and the next therophytes. The noticeable presence of therophytes in the initial stages of the development of vegetation was predicted but our study did not confirm this prediction. All the species recorded in vegetation patches on heaps of age class I were representative of four life-forms. No nanophanerophytes were present on the youngest heaps. The relatively high frequency of megaphanerophytes in vegetation of all age classes of heaps indicates that on this habitat tree seedling establishment take place very early in development. However trees are most abundant in age classes III and IV. Martinez-Ruiz and Marrs (2007) described the development of vegetation on the waste products of uranium ore mining and they found that when the substrate is poor there are a lot of species for which their participation does not change significantly over time. In particular the participation of shortlived species (mainly therophytes) does not change. Other results were obtained by Prach (1997) who studied the changes in species traits during primary and secondary succession and found that phanerophytes significantly increased and therophytes decreased during the first 10 years of succession. In our study hemicryptophytes remain the most frequent on heaps of the second and third age classes. Only in the oldest age class are megaphanerophytes the most often recorded life-form. Nanophanerophytes occurred in vegetation patches on heaps of the third age class and increased in frequency on the oldest heaps. Geophytes and hemicryptophytes did not exhibit any significant trend in the study conducted by Prach (1997). An increase in phanerophytes and a decrease in therophytes during early successional development have been reported (Glenn-Lewin et al. 1992), but our results do not confirm these findings.

Assuming that the productivity of vegetation on spoil heaps increases with time, we can agree with Down (1973), that at the more productive sites the species which represent therophytes declined over time. On the oldest heaps all of the analysed life-forms were recorded and most of them were present at high frequency. Cody and Diamond (1975) believed that species that occur later (perennials, shrubs and trees) in the development of the vegetation are plants which can reduce the sustainable level of resources, mainly sources of available nitrogen and carbon, below the threshold of survival for pioneer species (mostly therophytes). The frequency of all the life-form categories differed significantly between the vegetation patches on heaps of all age classes.

\section{Life strategy participation}

The species growing in the vegetation patches on heaps of age classes I and II are representative of different life strategies to those growing on heaps of age classes III and IV. The participation of competitors increased with time and on the oldest heaps competitors were recorded almost 10 times more often than on the youngest heaps. The concept of Grime's (2002) C-S-R strategy assumes that competitiveness (participation of species with a competitive strategy) increases with decreasing frequency of disturbance (as is the case in the course of succession). Those species with a ruderal strategy were the most frequent on heaps of age class I. It is not surprising that the participation of species which represent the ruderal strategy in the vegetation patches is the highest on the youngest spoil heaps. Our results show that the CSR strategists were most frequently recorded in vegetation patches on the youngest heaps and not the ruderals which could be expected in the early succession. A reduction in importance of species features associated with colonization ability (ruderal strategy) was demonstrated in studies on vegetation development on nutrient-poor habitats (Thompson et al. 2001). Huhta and Rautio (1998), similar to the study of Moog et al. (2005), explained the scarce occurrence of species with a ruderal strategy as being due to the lack of gaps in the cover crop. In our study there were plenty of gaps observed on the coal mine spoil heaps of age classes I, II and even III. Nevertheless, the habitat conditions were very unfavourable in terms of nutrients and also other resources such as water (Woźniak 2010). The gaps, in the case of post-industrial sites, should be considered, not only as an unoccupied space, but, as spaces with conditions appropriate for plants to persist and which could be colonised. In our study the participation of stress-tolerant species was different in the vegetation patches growing on spoil heaps representative of each of the four age classes. In Moog et al.'s study (2005) diversity was measured by the number of patches dominated by species with a particular life strategy. Such measurements as used in their study have revealed that diversity decreased with time, and this was also true in our study. However Prach (1997) found that participation of C-strategists significantly increased during the first 10 years of succession, while R-strategists decreased. The same results were obtained by Grime (1979). One explanation for the differences in results was proposed by Prach (2003) who said that in other geographical regions, and under specific environmental situations, spontaneous succession can undergo different trajectories. The stress-tolerant species did not exhibit any significant trend in the study conducted by Prach (1997). In our study the species which are stress-tolerators were most frequent on the oldest heaps and do not appear in any of the earlier stages, which indicated a strong statistically significant trend. Prach and Hobbs (2008) expected that low-productivity sites, such as those of post-mining areas, can be colonized by low-competitive, stress-tolerant species, which retreat from the surrounding eutrophicated landscape but these expectations are not confirmed by our results. In vegetation patches on the youngest heaps the second most common group of species were competitors, while stress-tolerant species occurred in vegetation patches on the oldest heaps. But Prach and Hobbs 
(2008) were right to expect that post-mining areas will consist of a refuge for rare and endangered species (Woźniak and Kompała 2001).

\section{Native species participation}

The participation of native species was found to be important in the vegetation patches on all the heaps of all age classes. The lack of importance of the participation of alien plants during the successional processes on man-made habitats might be surprising. Initially, it was thought that areas that are heavily modified will be very intensively colonised by alien species (Bradshaw 2002). However, preliminary field studies on postindustrial sites have shown that alien species are not present on industrialised areas (especially post-coal mining areas) any more frequently, or abundantly, than in any other kind of habitat (Woźniak 2001, 2003). According to Rostański (2006) a large portion of postindustrial sites remain, for many years after their abandonment, without human impact, and undergo spontaneous succession of the native flora. It has been stated (Hodačová and Prach 2003, Prach 2003) that many post-industrial sites even act as a refuge for wild, rare and endangered native plant and animal species. The functional importance of such post-industrial habitats in the landscape of industrialized regions is of much interest and of great value to the biodiversity of urban and industrialised areas (Box 1999). This trend was also previously suggested by Pickett et al. (2009) and Vitousek (1986). In this respect the lack of significance of the participation of alien species in our study is not surprising and is consistent with these previous results.

\section{Changes over time of PFG categories}

The results of our study show that the sequence of replacement during succession on hard coal heaps is as follows: the most commonly occurring species are represented by hemicryptophytes and geophytes in vegetation patches of the first and second age classes and are replaced by megaphanerophyte species in the oldest class. In the case of life strategies the species which are representatives of the CSR strategy and competitors are the most frequent in vegetation patches on heaps of all age classes. Further studies of this kind are required in order to add to this body of knowledge. The observed pattern of diversity does not conform with some previous findings and expectations, as indicated earlier in this discussion. It is evident that a scientific basis is necessary for any successful restoration (Palmer et al. 1997). It should also be considered that the specific environmental conditions on different types of post-industrial sites will require separate study as the spontaneous succession can take place in different ways on different substrates. Our results show that the participation of the species represented by the analyzed categories of PFGs differ significantly between vegetation patches recorded on heaps of different ages. Only the neophytes did not differ in their degree of participation in the different age classes.

Theory predicts that greater differences in the use of resources lead to increases in ecosystem function. Díaz and Cabido (2001) suggested that one of the best explanation for the effects of functional diversity on ecosystem function was that a higher diversity of functional traits increases resource-use efficiency in heterogeneous environments. This is related to the idea that certain species contribute disproportionately to ecosystem function and that those species possess particular functional traits that allow them to capture a greater proportion of the total available resources than other species. In our study we analyzed PFGs which do not relate to resource use efficiency, moreover, as Cadotte et al. (2011) underlined in practice, direct tests of the mechanistic relationship between functional diversity and ecosystem function are more difficult to perform. In our study it is difficult to explain how the PFGs affect the functioning of the studied vegetation. In order to explain this other features (i.e., seed mass, vegetative height, specific leaf area or density diameter) should be analyzed. However, it has been underlined that if functional diversity lacks variation (i.e., high redundancy), then ecosystem functional relationships of the plants should be negligible, but if there is variation in plant functional diversity, it could still explain variation in function even if an assessment of richness does not.

\section{Application of the findings to restoration ecology practice}

The aim of restoration ecologists is to increase the natural value of a disturbed site and establish self-sustaining vegetation cover on sites that have been degraded by anthropogenic activities (Bradshaw and Chadwick 1980) and to improve ecosystem functioning and services, such as productivity or protection, against erosion (Hobbs and Norton 1996). More recently, practitioners have attempted to create functional replicas of target communities on areas damaged by industry. In our opinion in some cases of post-industrial sites such examples of target communities might be those which are developing during the course of spontaneous succession, because their establishment and management are relatively costless and provide the opportunity for colonisation by species adapted to the local conditions.

The functional comparison of spontaneous vegetation developed on coal mine heaps, which can be characterized as a successful reclamation, presented here provides an additional aspect to restoration and reclamation ecology. A change from a species focus to a PFG approach as has already been presented by Latzel et al. (2011) might improve the effects of the restoration, or reclamation, activities; additionally, reclamation practice is often species focused and these are not always 
successful (Tropek et al. 2012). The presented approach is only a partial contribution to the complex spatiotemporal problem. The comprehensive answers to the above questions on vegetation development are also important from a practical reclamation point of view (Prach and Pyšek 2001; Prach et al. 2001). If the ecological rules are taken into account this should result in lowered costs for the reclamation and a reduction in management requirements in terms of extra seeding, planting, fencing and mowing.

Despite the generally increasing use of spontaneous succession in various restoration programs (Parker 1997; Prach 2003), the considerable potential that successional theory and the conclusions drawn from particular case studies can bring to restoration ecology is still only minimally exploited. As presented in this study the PFG composition of the spontaneous vegetation on hard coal heaps changes with time but the changes in some of the aspects are in contrast to some of the previous results and predictions concerning spontaneous succession.

\section{Conclusions}

1. On these man-made habitats we noted a small increase in species number and a significant increase in the sum of frequencies of all species with time.

2. The obtained results do not confirm the hypothesis of an increase in diversity measured in terms of the diversity of PFG categories.

3. The analyzed categories of PFGs differ significantly between vegetation patches recorded on heaps of sequential age.

4. It is important to allow natural succession to proceed in such places since this allows the colonization of the local species diversity which is particularly appropriate to the ecological conditions present in the locality.

5. Spontaneous succession can be a useful, low-cost, restoration tool in many situations.

Acknowledgments This study was supported by grants from the National Science Centre [Grant Number N305 046 336] in 2009-2011.

Open Access This article is distributed under the terms of the Creative Commons Attribution License which permits any use, distribution, and reproduction in any medium, provided the original author(s) and the source are credited.

\section{References}

Auclair AN, Goff FG (1971) Diversity relations in the upland forests of the western Great Lakes area. Am Nat 105:499-528

Balvanera P, Pfisterer AB, Buchmann N, He J-S, Nakashizuka T, Raffaelli D, Schmid B (2006) Quantifying the evidence for biodiversity effects on ecosystem functioning and services. Ecol Lett 9:1146-1156
Box J (1999) Nature conservation and post-industrial landscapes. Ind Archeol Rev 21:137-146

Bradshaw AD (1992) The biology of land restoration. In: Jain SK, Botsford LW (eds) Applied population biology. Kluwer Academic publishers, Dordrecht, The Netherlands

Bradshaw AD (1993) Restoration ecology as a science. Restor Ecol $1: 71-73$

Bradshaw AD (2002) Handbook of ecological restoration. Principles of restoration. In: Perrow MR, Davey AJ (eds) Cambridge University Press

Bradshaw AD, Chadwick MJ (1980) The restoration of land: the ecology and reclamation of derelict and degraded land. University of California Press, Los Angeles

Cabała J, Teper E, Teper L, Małkowski E, Rostański A (2004) Mineral composition in rhizosphere of plants grown in the vicinity of a $\mathrm{Zn}-\mathrm{Pb}$ ore flotation tailings pond. Acta Biol Crac Ser Bot 46:65-74

Cadotte MW, Carscadden K, Mirotchnick N (2011) Beyond species: functional diversity and the maintenance of ecological processes and services. J Appl Ecol 48:1079-1087

Chapin FS III, Zavaleta ES, Eviner VT, Naylor RL, Vitousek PM, Reynolds HL, Hooper DU, Lavorel S, Sala OE, Hobbie OE, Mach MC, Díaz S (2000) Functional and societal consequences of changing biotic diversity. Nature 405:234-242

Chmura D, Molenda T, Błońska A, Woźniak G (2011) Sites of leachate inflows on coalmine heaps as refuges of rare mountainous species. Pol J Environ Stud 20(3):551-557

Chmura D, Błońska A, Molenda T (2013) Hydrographic properties and vegetation differentiation in selected anthropogenic wetlands. International multidisciplinary scientific geoconference surveying geology and mining ecology management, SGEM, vol 1 , pp 555-562

Cody ML, Diamond JM (1975) Ecology and evolution of communities. Belknap Press, Cambridge, London

Cohn E, Rostański A, Tokarska-Guzik B, Trueman I, Woźniak G (2001) The flora and vegetation of an old solvay process tip in Jaworzno (Upper Silesia, Poland). Acta Societatis Botanicorum Poloniae 70(1):47-60

Díaz S, Cabido M (2001) Vive la difference: plant functional diversity matters to ecosystem processes. Trends Ecol Evol 16:646-655

Díaz S, Lavorel S, De Bello F, Quetier F, Grigulis K, Robson TM (2007) Incorporating plant functional diversity effects in ecosystem service assessments. Proc Natl Acad Sci 104:20684-20689

Down CG (1973) Life-form succession in plant communities on colliery waste. Environ Pollut 5:19-22

Ehrlich PR (1993) The scale of the human enterprise. In: Saunders DA, Hobbs RJ, Ehrlich PR (eds) Nature conservation 3: reconstruction of fragmented ecosystems: global and regional perspectives. Surrey Beatty \& Sons, Midland

Frank D, Klotz S (1990) Biologisch-ökologische Daten zur Flora der DDR. Wissenschaftliche Beiträge der Martin-Luther-Universität Halle-Wittenberg, Halle

Frouz J, Prach K, Pižl V, Háněl L, Starý J, Tajovský K, Materna J, Balık V, Kalčík J, Rehounková K (2008) Interactions between soil development, vegetation and soil fauna during spontaneous succession in post mining sites. Eur J Soil Biol 44:109-121

Glenn-Lewin DC, Peet RK, Veblen TT (1992) Plant succession. Theory and prediction. Chapman and Hall, London

Grime JP (1977) Evidence for the existence of three primary strategies in plants and its relevance to ecological and evolutionary theory. Am Nat 111:1169-1194

Grime JP (1979) Plant strategies and vegetation processes. Wiley, Chichester

Grime JP (2002) Plant strategies, vegetation processes, and ecosystem properties. Wiley, Chichester

Hobbs RJ, Norton DA (1996) Towards a conceptual framework for restoration ecology. Restor Ecol 4:93-110

Hodačová D, Prach K (2003) Spoil heaps from brown coal mining: technical reclamation vs. spontaneous re-vegetation. Restor Ecol 11:385-391 
Horn HS (1974) The ecology of secondary succession. Annu Rev Ecol Evol 4067:25-37

Huhta AP, Rautio P (1998) Evaluating the impacts of mowing: a case study comparing managed and abandoned meadow patches. Annales Botanici Fennici 35:85-99

Klotz S, Kuhn I, Durka W (2002) Biolflor-Eine Datenbank mit biologisch-okologischen Merkmalen zur Flora von Deutschland. Bundesamt fur Naturschutz. Bonn-Bad Godesberg, DE

Kompała A, Błońska A, Woźniak G (2004) Vegetation of the "Zabie Doły" area (Bytom) covering the wastelands of zinclead industry. Arch Environ Prot 30:59-76

Kompała-Bạba A, Bạba W (2013) The spontaneous succession in a sand-pit - the role of life history traits and species habitat preferences. Pol J Ecol 61:13-22

Krawiecowa A, Rostański K (1972) A project for improving of the classification of synanthropic plants. Phytocoenosis 1:217-222

Latzel V, Klimenšová J, Doležal J, Pyšek P, Tackenberg O, Prach K (2011) The association of dispersal and persistence traits of plants with different stages of succession in Central European man-made habitats. Folia Geobotanica 46:289-302

Margalef R (1968) Perspectives in ecological theory. University Chicago Press, Chicago

Martinez-Ruiz C, Marrs RH (2007) Some factors affecting successional change on uranium mine wastes: insights for ecological restoration. Appl Veg Sci 10:333-342

Mirek Z, Piękoś-Mirkowa H, Zając A, Zając M (2002) Flowering plants and pteridophytes of Poland a checklist. Szafer Institute of Botany, Polish Academy of Sciences, Kraków

Moog D, Kahmen S, Poschold P (2005) Application of CSR- and LHS-strategies for the distinction of differently managed grasslands. Basic Appl Ecol 6:133-143

Naeem S (2002) Ecosystem consequences of biodiversity loss: the evolution of a paradigm. Ecology 83:1537-1552

Naeem S, Wright JP (2003) Disentangling biodiversity effects on ecosystem functioning: deriving solutions to a seemingly insurmountable problem. Ecol Lett 6:567-579

Palmer MA, Ambrose RF, Poff NL (1997) Ecological theory and community restoration ecology. Restor Ecol 5:291-300

Parker VT (1997) The scale of successional models and restoration objectives. Restor Ecol 5:301-306

Pickett STA, Cadenasso ML, Meiners SJ (2009) Ever since Clements: from succession to vegetation dynamics and understanding to intervention. Appl Veg Sci 12:9-21

Pineda FD, Nicolas JP, Ruiz M, Peco B, Bernaldez FG (1981) Ecological succession in oligotrophic pastures of Central Spain. Vegetation 44:165-176

Prach K (1997) Changes in species traits during succession: a search for pattern. Oikos 79:201-205

Prach K (2003) Spontaneous succession in Central-European manmade habitats: what information can be used in restoration practice? Appl Veg Sci 6:125-129

Prach K, Hobbs R (2008) Spontaneous succession versus technical reclamation in the restoration of disturbed sites. Restor Ecol 16:363-366

Prach K, Pyšek P (2001) Using spontaneous succession for restoration of human-disturbed habitats: experience from Central Europe. Ecol Eng 17:55-62

Prach K, Pyšek P, Smilauer P (1997) Changes in species traits during succession: a search for pattern. Oikos 79:201-205

Prach K, Pyšek P, Bastl M (2001) Spontaneous vegetation succession in human-disturbed habitats: a pattern across seres. Appl Veg Sci 4:83-88

Rahmonov O (2009) The chemical composition of plant litter of black locust (Robinia pseudoacacia L.) and its ecological role in sandy ecosystems. Acta Ecol Sinica 29:237-243

Rahmonov O, Rahmanova M, Snytko VA, Szczypel T (2011) Anthropogenic disturbance to vegetation on the polygon-transect in the Kulikalon depression (Tajikistan). Geogr Nat Resour 32:386-393

Raunkiaer C (1934) The Life Forms of Plants and Statistical Plant Geography, being the collected papers of C. Raunkiaer. Oxford University Press, Oxford (reprinted 1978)
Rosenfeld JS (2002) Functional redundancy in ecology and conservation. Oikos 98:156-162

Rostański A (2005) Specific features of the flora of colliery spoil heaps in selected European regions. Pol Bot Stud 19:97-103

Rostański A (2006) Spontaneous plant cover on colliery spoil heaps in Upper Silesia (Southern Poland). University of Silesia, Katowice

Rostański A, Woźniak G (2007) Trawy (Poacae) występujące spontanicznie na terenie nieużytków poprzemysłowych. Fragmenta Flororistica et Geobotanica Polonica 9:31-42

Siegel S, Castellan NJ (1988) Non-parametric statistics for the behavioral sciences. McGraw-Hill, New York, pp 213-215

Smith MD, Knapp K (2003) Dominant species maintain ecosystem function with non-random species loss. Ecol Lett 6:509-517

Šnajdr J, Dobiášová P, Urbanová M, Petránková M, Cajthaml T, Frouz J, Baldrian P (2013) Dominant trees affect microbial community composition and activity in post-mining afforested soils. Soil Biol Biochem 56:105-115

Thompson K, Hodgson JG, Grime PJ, Burke MJW (2001) Plant trait and temporal scale: evidence from a 5-year invasion experiment using native species. J Ecol 89:1054-1060

Tropek R, Kadlec T, Hejda M, Kocarek P, Skuhrovec J, Malenovsky I, Vodka S, Spitzer L, Banar P, Konvicka M (2012) Technical reclamation are wasting the conservation potential of post-mining sites. A case study of black coal spoil dumps. Ecol Eng 43:13-18

Urbanová M, Kopecky J, Valaskova V, Saganova-Mareckova M, Elhottova D, Kyselkova M, Moenne-Loccoz Y, Baldrian P (2011) Development of bacterial community during spontaneous succession on spoil heaps after brown coal mining. FEMS Microbiol Ecol 78:59-69

Vitousek PM (1986) Biological invasions and ecosystem properties: can species make a difference? In: Mooney HA, Drake JA (eds) Ecology of biological invasions of North America and Hawaii. Springer, New York

Wang H, Chen H (2013) Plant functional groups based on vegetative and reproductive traits in a subtropical forest community. Jpn For Soc 18:482-490

Woźniak G (2001) Invasive plants involved in primary succession on post-industrial areas Upper Silesia (Poland). In: Brundu G, Brock J, Camada I, Child L, Wade M (eds) Plant invasions: species ecology and ecosystem management. Backhuys Publishers, Leiden

Woźniak G (2003) The neophyte establishment in plant communities of post-industrial waste sites (Upper Silesia; Poland). In: Child LE, Brock JH, Brundu G, Prach K, Pyšek P, Wade PM, Williamson $M$ (eds) Plant invasions: ecological threats and management solutions. Backhuys Publishers, Leiden

Woźniak G (2006) Colonisation process on coal mine sedimentation pools (Upper Silesia, Poland). Pol Bot Stud 22:561-568

Woźniak G (2010) Diversity of vegetation on coal-mine heaps of the Upper Silesia (Poland). Szafer Institute of Botany, Polish Academy of Sciences, Kraków

Woźniak G, Kompała A (2001) Ecology of spontaneous vegetation on post-industrial waste lands (Upper Silesia-Poland). In: Sarsby RW, Meggyes T (eds) Green 3. The exploitation of natural resources and the consequences. Thomas Telford, London, pp 568-573

Woźniak G, Pasierbiński A, Rostański A (2003) The diversity of spontaneous woodland vegetation on coals mine heaps of Upper-Silesian Industrial Region. Arch Environ Prot 29:93-105

Woźniak G, Chmura D, Błońska A, Tokarska-Guzik G, Sierka E (2011) Applicability of the concept of functional groups for analysis of spatiotemporal vegetation changes on manmade habitats. Pol J Environ Stud 20:623-631

Zar JH (1999) Biostatistical analysis. Prentice Hall, Upper Saddle River

Zarzycki K, Trzcińska-Tacik H, Rożański W, Szeląg Z, Wołek J, Korzeniak U (2002) Ecological indicator values of vascular plants of Poland. Wydawnictwo Instytutu Botaniki PAN, Kraków 